David J. Armitage

\title{
Theories of Poverty in the World of the New Testament
}

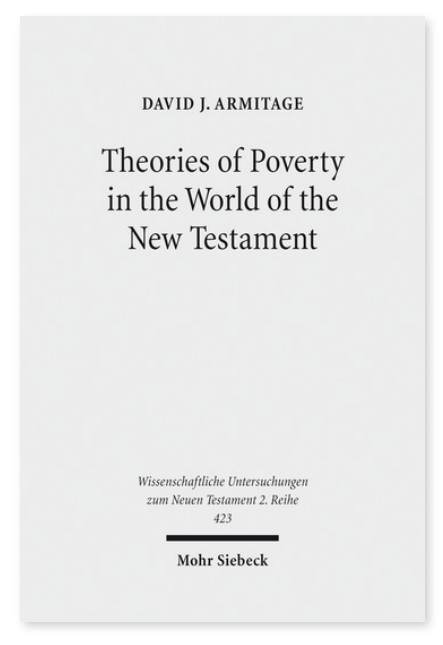

2016. XVI, 301 Seiten. WUNT II 423

ISBN 978-3-16-154400-2

DOI 10.1628/978-3-16-154400-2

eBook PDF 104,00€

ISBN 978-3-16-154399-9

fadengeheftete Broschur 104,00€
[Gedanken zur Armut in der Welt des Neuen Testaments.]

Veröffentlicht auf Englisch.

David J. Armitage untersucht die Deutungen von Armut im griechisch-römischen und jüdischen Kontext des Neuen Testaments und analysiert in diesem Zusammenhang, als wie profiliert die Einstellungen gegenüber der Armut im Neuen Testament verstanden werden können. Begründungen für die Not der Armen sowie vermeintliche Lösungen des Problems der Armut werden erörtert, wobei die Bedeutung von Fragen zum Verhältnis von Armut zu Tugend und Laster vor griechischrömischem Hintergrund sowie die Rolle von Schicksal und Zufall für die Verarmung erläutert werden. Solche

Verhältnisbestimmungen waren peripher für Teile der jüdischen Überlieferung, in denen der Armutsdiskurs durch einen narrativen Rahmen geformt wurde, der Sünde, Fluch und die erhoffte Rettung der rechtschaffenen Armen umfasste. Diese Elemente finden sich in neutestamentlichen Texten. Diese bekräftigten die weitgestreute Sorge der Juden um die Armen, während sie die Hoffnung auf ein Ende der Armut rund um eine eingeführte Eschatologie, die sich um Jesus dreht, umgestalteten.

David J. Armitage Born 1975; 2015 PhD in Theology, University of Nottingham.
Jetzt bestellen:

https://mohrsiebeck.com/buch/theories-of-poverty-in-the-world-of-the-new-testament-9783161544002?no_cache=1 order@mohrsiebeck.com

Telefon: $+49(0) 7071-923-17$

Telefax: +49 (0)7071-51104 